cant impact on the difference between the mean time elapsed between the Ph.D. and first publication in the APSR for the first and second 20 -year period.

10. Of course a caveat is needed here. First of all, we are making generalizations about the profession from trends emerging in only five political science and one sociology journal. We have no evidence to indicate whether or not similar trends of increasing collaboration are appearing in other political science journals or in journals from other social science subfields such as anthropology or psychology. Nevertheless, if our explanation of the APSR trend is correct, then we would expect this trend to be visible in other political science journals, as well as the journals of other social science disciplines. Our future research plans include undertaking an analysis of yet other journals to determine if we have discovered a trend that appears in those journals as well. Until that work is complete, our results must be viewed as inconclusive. Secondly, the reader should be reminded that the data dealing with time of getting the $\mathrm{Ph}$.D. is still somewhat incomplete and as indicated earlier in the text is based upon a sample of 769 individuals out of the 1,628 authors. Given these limitations our conclusions must remain somewhat speculative.

\section{References}

Cnudde, Charles F. 1986. "Care in Using the Social Sciences Citation Index: Comment on Klingemann's Method." PS 19: 850-52.

Christenson, James A., and Lee Sigelman. 1985. "Accrediting Knowledge: Journal Stature and Citation Impact in Social Science." Social Science Quarterly 66: 964-76.

Festinger, L. 1954. "A Theory of Social Comparison Processes." Human Relations 7:117-40.

Garand, James C. 1990. "An Alternative Interpretation of Recent Political Science Journal Evaluations." PS 23:448-51.

Klingemann, Hans-Dieter. 1986. "Ranking the Graduate Departments in the 1980s: Toward Objective Qualitative Indicators." $P S$ 19:651-61.

Klingemann, Hans-Dieter, Bernard Grofman, and Janet Campagna. 1989. "The Political Science 400: Citations by Ph.D. Cohort and by Ph.D.-Granting Institution." PS 22:258-70.

Patterson, Samuel C., Brian D. Ripley, and Barbara Trish. 1988. "The American Po- litical Science Review: A Retrospective of the Last Year and the Last Eight Decades." PS 21:908-25.

Powell, G. Bingham, Jr. 1994. "Report of the Managing Editor of the American Political Science Review, 1993-94." PS 27:759-65.

Tajfel, Henri. 1981. Human Groups and Social Categories. Cambridge: Cambridge University Press.

\section{About the Authors}

Arthur H. Miller is professor of political science and director of the Iowa Social Science Institute at the University of Iowa.

Charles Tien is a Ph.D. candidate in political science at the University of Iowa. His dissertation research deals with presidential and congressional interactions in the federal budgetary process.

Andrew Peebler is a graduating senior in political science and an assistant study director in the Iowa Social Science Institute at the University of Iowa.

\title{
A Brief Citation Guide for Internet Sources in History and the Humanities (Version 2.0)
}

\author{
Melvin E. Page, $H$-Net and East Tennessee State University
}

The following suggestions for citations of Internet sources in history and the historically based humanities are derived from the essential principles of academic citation in Kate L. Turabian, A Manual for Writers of Term Papers, Theses, and Dissertations, 5th ed. (Chicago, University of Chicago Press, 1987). I have also drawn upon suggestions from some of the works listed below. The guide has been improved by the students of my Historical Methods classes at East Tennessee State University and my fellow H-AFRICA editors whom I thank for their assistance.

Since the Internet is an evolving institution, this guide is not intended to be definitive. Correc-

\footnotetext{
* Copyright Melvin E. Page, 1995. This document may be reproduced and redistributed, but only in its entirety and with full acknowledgment of its source and authorship.
}

tions, additions, comments, suggestions, and criticisms are therefore welcome. Please address them to the author at: <pagem@etsuarts. east-tenn-st.edu. $>$.

When the need for revisions and updates become apparent, new versions of the guide will be issued. The most recent version will be stored at the following URL, which is case sensitive: < gopher://h-net. msu.edu:70/00/lists/H-AFRICA/ internet-cit>.

\section{Bibliographic Citations}

\section{Basic Citation Components and Punctuation}

Author's Last Name, First Name. <author's internet address, if available $>$. "Title of Work" or "title line of message." In "Title of Complete Work" or title of list/site as appropriate. <internet address >. Date, if available.
The samples below indicate how citations of particular electronic sources might be made.

\section{Listserv Messages}

Walsh, Gretchen. <gwalsh@acs.bu.edu>. "REPLY: Using African newspapers in teaching." In H-AFRICA. $<$ h-africa@msu.edu>.18 October 1995.

\section{World Wide Web}

Limb, Peter. "Relationships between Labour \& African Nationalist/Liberation Movements in Southern Africa." $<$ http://neal.ctstateu.edu/history/ world_history/archives/limb-1.html>. May 1992.

\section{FTP Site}

Heinrich, Gregor. <100303.100@compuserve.com>. "Where There Is Beauty, There Is Hope: Sau Tome e Principe." <ftp.cs.ubc.ca/pub/local/ FAQ/african/gen/saoep.txt $>$. July 1994. 


\section{Gopher Site}

"Democratic Party Platform, 1860." $<$ wiretap.spies.com> [Wiretap Online Library/Civic \& Historical/Political Platforms of the U.S.]. 18 June 1860.

Kirshenblatt-Gimblett, Barbara. "Making Difference." < gopher.uic.edu> [The Researcher/History/H-Net/ H-Amstdy (American Studies)/Essays \& Discussions About American Studies]. 20 July 1995.

\section{Usenet Group Messages}

Dell, Thomas.<dell@wiretap.spies. com>. "[EDTECH] EMG: Sacred Texts (Networked Electronic Versions)." In < alt.etext $>.4$ February 1993.

Legg, Sonya. <legg@harquebus.cgd. ucar.edu $>$. "African history book list." In <soc.culture.african>. 5 September 1994.

\section{E-mail Messages}

Page, Mel.<pagem@etsuarts.easttenn-st.edu>. "African dance . . . and Malawi." Private e-mail message to Masankho Banda, <mbanda@ igc.apc.org >. 28 November 1994.

\section{Footnote and Endnote Citations}

\section{Basic Citation Components and Punctuation}

Note number. Author's First name and Last name, <author's internet address, if available $>$, "Title of Work" or "title line of message," in "Title of Complete Work" or title of list/ site as appropriate, <internet address $>$, date if available.

The examples below indicate how citations of particular electronic sources might be made.

\section{Listserv Messages}

1. Gretchen Walsh, <gwalsh@acs.bu. edu>, "REPLY: Using African newspapers in teaching," in $\mathrm{H}$ AFRICA, <h-africa@msu.edu>, 18 October 1995.

\section{World Wide Web}

2. Peter Limb, "Relationships between Labour \& African Nationalist/Liberation Movements in Southern Africa," $<$ http://neal.ctstateu.edu/history/ world_history/archives/limb-l.html>, May 1992.

\section{FTP Site}

3. Gregor Heinrich, <100303.100@ compuserve.com $>$, "Where There Is Beauty, There Is Hope: Sao Tome e Principe," <ftp.cs.ubc.ca/pub/local/ FAQ/african/gen/saoep.txt>, July 1994.

4. Sonya Legg, $<$ legg@harquebus.cgd.ucar.edu>, "African history book list," in < soc. culture.african>, 5 September 1994.

\section{Gopher Site}

5. "Democratic Party Platform, 1860," $<$ wiretap.spies.com> [Wiretap Online Library/Civic \& Historical/Political Platforms of the U.S.], 18 June 1860.

6. Barbara Kirshenblatt-Gimblett, "Making Difference," < gopher. uic.edu $>$ [The Researcher/History/
H-Net/H-Amstdy (American Studies)/Essays \& Discussions About American Studies>, 20 July 1995.

\section{Usenet Group Messages}

7.Thomas Dell, <dell@wiretap.spies. com> "[EDTECH] EMG: Sacred Texts (Networked Electronic Versions)," in <alt.etext>, 4 February 1993.

\section{E-Mail Messages}

8. Mel Page, <pagem@etsuarts.easttenn-st.edu>, "African dance ... and Malawi," private e-mail message to Masankho Banda, <mbanda@igc. apc.org>, 28 November 1994.

\section{Additional Source Material on Internet Citations}

Dodd, Sue A. "Bibliographic References for Computer Files in the Social Sciences: A Discussion Paper." < gopher://info.monash.edu.au:70/00/ handy/cites $>$. Revised May 1990. \{Published in ASSIST Quarterly, 14, 2(1990): 14-17.

Li, Xia and Nancy Crane. Electronic Style: A Guide to Citing Electronic Information. Westport: Meckler, 1993.

University of Chicago Press. Chicago Guide to Preparing Electronic Manuscripts: for Authors and Publishers. Chicago: University of Chicago Press, 1987.

Walker, Janice R. "MLA-Style Citations of Internet Sources." < http:// www.cas.usf.edu/english/walker/ janice.html>. April 1995. 